Penelitian

\title{
Pola Resistensi Antibiotik pada Escherichia coli Penghasil ESBL dari Sampel Lingkungan di RPH-R Kota Bogor
}

\author{
(Antibiotic Resistance of ESBL-Producing Escherichia coli from Environmental Samples \\ in Bogor Slaughterhouse) \\ Ratna Normaliska ${ }^{1,2^{*}}$, Mirnawati Bachrum Sudarwanto ${ }^{3}$, Hadri Latif ${ }^{3}$ \\ 'Balai Besar Karantina Pertanian Tanjung Priok, Badan Karantina Pertanian \\ ${ }^{2}$ Program Studi Kesehatan Masyarakat Veteriner Sekolah Pascasarjana IPB \\ ${ }^{3}$ Departemen Ilmu Penyakit Hewan dan Kesehatan Masyarakat Veteriner, Fakultas Kedokteran Hewan, IPB \\ *Penulis untuk korespondensi: drh_ratnanorma@yahoo.com \\ Diterima 7 Juni 2018, Disetujui 5 Maret 2019
}

\begin{abstract}
ABSTRAK
Extended spectrum 6-lactamase (ESBL) adalah enzim yang dapat menghidrolisis berbagai jenis antibiotik $\beta$-laktam termasuk generasi ketiga sefalosporin spektrum luas dan monobaktam. Tujuan dari penelitian ini adalah untuk melihat kepekaan dan resistensi Escherichia coli penghasil ESBL terhadap beberapa antibiotik. Metode yang digunakan adalah difusi cakram pada media Mueller Hinton Agar (MHA) dan interpretasi hasil mengacu pada Clinical and Laboratory Standards Institute (CLSI). Isolat Escherichia coli penghasil ESBL $(n=10)$ diisolasi dari total 80 sampel lingkungan di RPHR Kota Bogor. Pengambilan sampel dilakukan sebelum proses pemotongan hewan. Hasil pengujian resistensi antibiotik menunjukkan isolat resisten terhadap penisilin 100\%, amoksisilin 100\%, streptomisin $70 \%$, trimetoprim-sulfametoksasol $60 \%$, dan tetrasiklin 30\%. Bakteri E. coli penghasil ESBL di lingkungan RPHR Kota Bogor telah mengalami resistensi terhadap antibiotik dan berpotensi menyebarkan gen resisten tersebut ke bakteri lain. Hasil ini dapat menimbulkan risiko pada kesehatan masyarakat, oleh karena itu diperlukan evaluasi dan pengendalian lebih lanjut.
\end{abstract}

Kata kunci: E. coli, ESBL, lingkungan, resistensi antibiotik

\begin{abstract}
Extended spectrum $\beta$-lactamase (ESBL) is an enzyme that could hydrolyze various type of $\beta$-lactam antibiotics included the third generation of broad spectrum cephalosporin and monobactam. The study was conducted to investigate effectiveness and resistance of ESBL-producing E. coli against several antibiotics. The method that was used is disk diffusion on Mueller Hinton Agar (MHA) following Clinical and Laboratory Standards Institute (CLSI) guidelines for interpretation. Isolate ESBL-producing $E$. coli $(n=10)$ was isolated from 80 environmental samples from Bogor Slaughterhouse, before the slaughtering process. The isolated ESBL-producing E. coli showed resistance towards penicillin $100 \%$, amoxicillin $100 \%$, streptomycin $70 \%$, trimethoprim-sulfamethoxazole $60 \%$, and tetracycline $30 \%$ ESBL producing $E$. coli in the environment slaughterhouse has experienced resistance against antibiotics and the potential to spread of the resistant genes to other bacteria. This result may pose a public health risk which requires further evaluation and control.
\end{abstract}

Keywords: E. coli, ESBL, environment, antibiotic resistance 


\section{PENDAHULUAN}

Bakteri E. coli tergolong dalam gram negatif, tidak membentuk spora, berbentuk batang, motil dengan flagela peritrikus atautidak motil, tumbuh pada MacConkey agar dengan diameter koloni 2 sampai $3 \mathrm{~mm}$ berwarna merah atau tidak berwarna (PHAC, 2012). Beberapa strain E. coli menyebabkan infeksi saluran kencing, bakteremia, diare, diare berdarah, dan meningitis neonatal pada manusia dan hewan (Palaniappan et al., 2006; CDC, 2016). Infeksi lain seperti pneumonia dan sepsis pada manusia, serta mastitis pada sapi perah juga terjadi akibat infeksi bakteri E. coli (Braun et al., 2016).

Habitat umum E. coli adalah saluran pencernaan manusia dan hewan (Sousa, 2006). Ada strain E. coli yang bersifat komensal, tidak berbahaya, dan ada yang bersifat patogen pada manusia dan hewan (Van Elsas et al., 2011). E. coli dapat ditemukan di tanah dan air sebagai akibat dari kontaminasi feses. Keberadaannya digunakan sebagai indikator kualitas air dan/atau kualitas makanan yang buruk (Sousa, 2006; Aidara-Kane et al., 2013). E. coli dapat ditemukan di lingkungan (seperti air, tanah, udara, dan debu), peralatan yang dipergunakan selama produksi dan para pekerja. E. coli dapat digunakan sebagai indikator resistensi antimikrob (Ariyanti et al., 2007; Loncaric et al., 2013).

Extended spectrum B-lactamase (ESBL) merupakan enzim yang memiliki kemampuan untuk menghidrolisis dan menyebabkan resistensi terhadap berbagai jenis antibiotik $\beta$-laktam, termasuk generasi ketiga broad-spectrum sefalosporin (misalnya, sefotaksim, seftriakson, dan seftazidim) dan monobaktam (misalnya aztreonam), tetapi tidak mampu memengaruhi sefamisin (misalnya sefoksitin dan sefotetan) dan karbapenem (misalnya imipenem, meropenem, dan ertapenem), dan aktivitasnya dihambat oleh asam klavulanat (Pitout dan Laupland, 2008; Khanfar et al., 2009). ESBL menyebabkan resistensi terhadap antibiotik golongan penisilin, sefalosporin, dan aztreonam, selain itu juga terhadap kelas antibiotik lain, termasuk aminoglikosida, trimetoprim-sulfametoksasol, dan kuinolon (Paterson, 2000).

Resistensi bakteri penghasil ESBL terhadap berbagai antibiotik telah banyak dilaporkan. Di Indonesia, penelitian pada sampel susu dari peternakan sapi perah di Jawa Barat menunjukkan bahwa tujuh dari 80 peternakan yang diambil sampel, isolatnya positif Klebsiella pneumoniae penghasil ESBL (Sudarwanto et al., 2015). Penelitian E. coli penghasil ESBL dari feses sapi potong di RPH-R Kota Bogor adalah sebesar 15,8\% (Sukmawinata, 2015), dan setelah diuji ke tingkat molekuler menggunakan
PCR diperoleh 19 sampel dari 220 sampel (8.6\%) positif terdeteksi E. coli penghasil ESBL tipe CTX-M (Sudarwanto et al., 2016). E. coli penghasil ESBL juga ditemukan pada sampel feses ayam broiler di Sentra Pemotongan Ayam Kota Bogor sebanyak 12 dari 200 sampel yang diperiksa (6.0\%), setelah diuji ke tingkat molekuler diperoleh $E$. coli penghasil ESBL tipe CTX- M-1 dan CTX-M-55 masing-masing sebanyak 6 sampel (Lukman et al., 2016).

Penggunaan antibiotik di bidang pertanian dan peternakan semakin meningkat. Hal ini menjadi masalah kesehatan global karena perkembangannya dapat menyebabkan bakteri menjadi resisten terhadap antibiotik. Kotoran hewan menjadi sumber utama bagi bakteri yang telah resisten untuk menyebar ke lingkungan, khususnya tanah (Ibrahim et al., 2016). Penggunaan obat-obatan, termasuk antibiotik, dalam peternakan tidak dapat dihindarkan. Tuntutan untuk mendapatkan ternak yang bebas penyakit dan produksi yang optimal, maka ketersediaan obat hewan sangat diperlukan, di samping penggunaan bibit unggul dan pemeliharaannya yang memakan waktu lama. Di peternakan, antibiotik digunakan secara selektif dan sesuai tujuan, seperti untuk pengobatan sehingga mengurangi risiko kematian, mengembalikan kondisi ternak yang dapat berproduksi secara normal, dan mencegah penyebaran mikroorganisme patogen ke ternak yang lain (Murdiati, 1997; Yuningsih, 2005).

$\mathrm{Di}$ samping untuk pengobatan, antibiotik digunakan untuk memacu pertumbuhan (growth promotor) sehingga mempercepat pertumbuhan. Biasanya antibiotik ditambahkan sebagai imbuhan pakan (feed additive), secara tidak langsung berpengaruh pada pertumbuhan mikroorganisme perusak zat-zat gizi dalam pakan dan merangsang pertumbuhan mikroorganisme pembentuk asam amino (Yuningsih, 2005). Pemakaian antibiotik yang terus menerus dan tidak terkontrol akan mengakibatkan meningkatnya kelompok bakteri yang resisten terhadap antibiotik (Kusumaningsih, 2012).

\section{BAHAN DAN METODE}

\section{Bahan}

Bahan yang digunakan dalam penelitian adalah sampel lingkungan yang terdiri atas swab lantai pemotongan hewan, swab lantai penanganan karkas, swab lantai penanganan jeroan, swab besi penggantung karkas, swab keranjang untuk kepala dan kaki, swab keranjang jeroan, swab baju pemanggul 
karkas, swab sarung pisau, swab sepatu boot pekerja, swab alat angkut, air kran, dan air selokan, yang diambil sebelum proses pemotongan (praproduksi) di RPHR Kota Bogor, buffer peptone water (BPW) 0.1\% (Oxoid CM1049, Inggris), sefotaksim $1 \mathrm{mg} / \mathrm{l}$, MacConkay agar (Merck 1.05465.0500, Jerman), Mueller Hinton agar (Merck 1.05437.0500, Jerman), larutan $\mathrm{KOH} 3 \%$, larutan kristal violet, larutan lugol, larutan aseton alkohol, larutan safranin, strip tes oksidase (Oxoid MB0266A, Inggris), tryptone broth (Oxoid LPo042, Inggris), reagen Kovacs (Merck 1.09293.0100, Jerman), larutan a-naphtol, MR-VP medium (Oxoid CMo043, Inggris), tryptic soy agar (TSA) (Merck 1.05458.0500, Jerman), Brilliance ${ }^{\mathrm{TM}}$ ESBL Agar (Oxoid, Inggris), gliserol 85\%, McFarland suspension $0.5, \mathrm{NaCl} 0.85 \%$, cakram antibiotik, isolat E. coli strain ATCC 25922, Klebsiella pneumoniae strain ATCC 700603, alkohol 96\%, MASTDISCS ${ }^{\mathrm{TM}}$ D68C (Mastgroup, Jerman), dan kit API 20E (Biomérieux, Amerika Serikat).

Isolasi dan Identifikasi E. coli Penghasil ESBL (Sudarwanto et al., 2015)

Sebanyak 80 sampel dihomogenisasi menggunakan tube shaker dengan menambahkan larutan buffered peptone water (BPW) 0.1\% dengan perbandingan 1:10. Selanjutnya larutan diambil sebanyak $10 \mathrm{ml}$ dan ditambahkan $20 \mu \mathrm{L}$ sefotaksim (1 $\mathrm{mg} / \mathrm{l})$ lalu diinkubasi selama 24 jam pada suhu $37^{\circ} \mathrm{C}$. Sampel diambil 1 ose lalu digoreskan pada agar MacConkay yang mengandung sefotaksim $1 \mu \mathrm{g} / \mathrm{ml}$, diinkubasi pada suhu $37{ }^{\circ} \mathrm{C}$ selama 24 jam. Koloni dengan bentuk bulat, berwarna merah, dan dikelilingi zona keruh diduga sebagai E. coli. Koloni yang diduga E. coli ditanam ke media tryptic soy agar dan tryptic soy agar miring yang diinkubasi 24 jam pada suhu $37^{\circ} \mathrm{C}$. Koloni yang tumbuh diuji $\mathrm{KOH}$, pewarnaan Gram, uji oksidase, dan uji biokimia (indol, methyl red, Voges-Proskauer, dan sitrat/IMViC serta uji motilitas pada media SIM). Koloni diduga $E$. coli penghasil ESBL juga ditanam pada agar L-EMBA dan Brilliance ${ }^{\mathrm{TM}}$ ESBL Agar. Hasil reaksi uji biokimia E. coli mengacu pada Standar Nasional Indonesia (SNI) 2897 Tahun 2008. Isolat disimpan dalam tryptic soy broth pada suhu $-20^{\circ} \mathrm{C}$ yang mengandung $20 \%$ gliserol sampai pengerjaan tahap berikutnya. Isolat yang diduga $E$. coli diidentifikasi ke tingkat spesies menggunakan kit uji cepat API $20 \mathrm{E}$ diinkubasi pada suhu $37^{\circ} \mathrm{C}$ selama 24 jam. Pembacaan hasil uji menggunakan kit uji cepat API $20 \mathrm{E}$ dilakukan secara online melalui http:// apiweb.biomerieux.com.
Konfirmasi ESBL dan Uji Kepekaan Isolat E. coli terhadap Antibiotik

Konfirmasi ESBL dalam penelitian dilakukan menggunakan MASTDISCS ${ }^{\mathrm{TM}}$ D68C. Konfirmasi ESBL dan uji kepekaan isolat $E$. coli penghasil ESBL menggunakan metode difusi cakram berdasarkan panduan dari Clinical and Laboratory Standar Institute (CLSI) (CLSI, 2014). Biakan murni disiapkan dalam bentuk suspensi yang setara dengan kekeruhan $0.5 \mathrm{McFarland}\left(1-2 \times 10^{8} \mathrm{cfu} / \mathrm{ml}\right)$. Biakan tersebut diambil menggunakan cotton swab steril dan digoreskan pada Mueller Hinton agar (MHA) sampai seluruh permukaan cawan petri tertutup. Selanjutnya dengan metode Kirby-Bauer kertas cakram yang berisi antibiotik diletakkan di atas MHA dengan jarak antara 25-30 mm dan diinkubasikan pada suhu $35^{\circ} \mathrm{C}$ selama 24 jam. Antibiotik yang digunakan dalam penelitian adalah penisilin, amoksisilin, trimetropim sulfametoksasol, streptomisin, dan tetrasiklin. E. coli strain ATCC 25922 dan Klebsiella pneumoniae strain ATCC 700603 digunakan untuk melihat performa terhadap deteksi agen penghasil ESBL dan sebagai kontrol pada setiap uji kepekaan terhadap antibiotik. E. coli strain ATCC 25922 sebagai kontrol negatif, dan Klebsiella pneumoniae strain ATCC 700603 sebagai kontrol positif.

\section{Analisis Data}

Data penelitian dianalisis secara deskriptif menggunakan Microsoft Excel 2010. Hasil data berupa tabel dan gambar mengenai resistensi $E$. coli penghasil ESBL terhadap antibiotik dari sampel lingkungan sebelum proses produksi (proses pemotongan hewan) di RPH- R Kota Bogor, Jawa Barat.

\section{HASIL}

Berdasarkan hasil penelitian, E. coli yang diduga sebagai penghasil ESBL ditunjukkan dengan adanya pertumbuhan pada MacConkay agar, Levine eosin methylene blue agar (L-EMBA) dan Brilliance ${ }^{\mathrm{TM}} \mathrm{ESBL}$ Agar (Gambar 1a, 1b, dan 1C).

Uji konfirmasi ESBL dilakukan untuk memastikan bahwa E. coli yang ditemukan adalah benar E. coli penghasil ESBL. Uji konfirmasi ESBL menggunakan MASTDISCS ${ }^{\mathrm{TM}}$ D68C, diperoleh E. coli penghasil ESBL sebanyak 10 sampel dari 80 sampel yang diperiksa (12.5\%). Isolat yang positif E. coli penghasil ESBL diperoleh dari beberapa lokasi pengambilan sampel yang telah ditentukan seperti keranjang untuk kepala dan kaki, sepatu boot pekerja, besi penggantung 

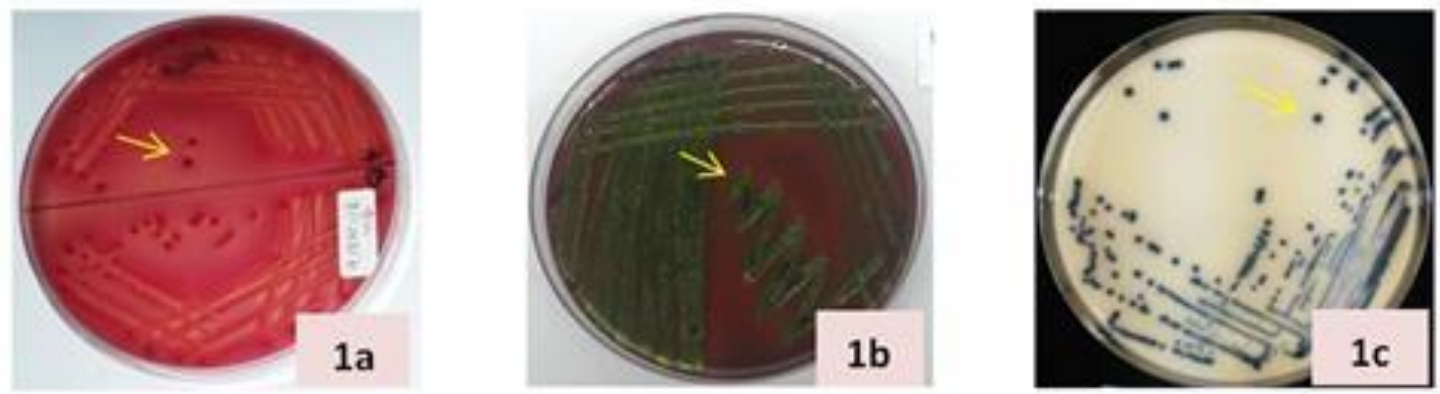

Gambar 1 Koloni diduga E. coli penghasil ESBL.1a: koloni pada MacConkay Agar, 1b: koloni pada L-EMBA, dan 1c: koloni pada Brilliance ${ }^{\mathrm{TM}}$ ESBL Agar

Tabel 1 Bakteri E. coli penghasil ESBL yang ditemukan berdasarkan lokasi pengambilan sampel

\begin{tabular}{lcccccc}
\hline & \multicolumn{5}{c}{ Lokasi pengambilan sampel } \\
\cline { 2 - 7 } Isolat bakteri & $\begin{array}{c}\text { Keranjang } \\
\text { untuk kepala } \\
\text { dan kaki }\end{array}$ & $\begin{array}{c}\text { Sepatu } \\
\text { boot } \\
\text { pekerja }\end{array}$ & $\begin{array}{c}\text { Besi } \\
\text { penggantung } \\
\text { karkas }\end{array}$ & $\begin{array}{c}\text { Alat } \\
\text { angkut/truk }\end{array}$ & $\begin{array}{c}\text { Lantai } \\
\text { Pemotongan }\end{array}$ & Sarung Pisau \\
\hline $\begin{array}{l}\text { E. coli penghasil } \\
\text { ESBL }(\mathrm{n}=10)\end{array}$ & 4 & 2 & 1 & 1 & 1 & 1 \\
\hline
\end{tabular}

karkas, alat angkut/truk, lantai pemotongan, dan sarung pisau (Tabel 1).

E. coli penghasil ESBL yang ditemukan, selanjutnya dilakukan pengujian sensitivitas terhadap beberapa antibiotik, seperti penisilin, amoksisilin, streptomisin, trimetoprimsulfametoksasol, dan tetrasiklin. Hasil pengujian sensitivitas isolat $E$. coli penghasil ESBL terhadap antibiotik disajikan pada Tabel 2 dan pola resistensi isolat $E$. coli penghasil ESBL terhadap antibiotik disajikan pada Tabel 3.

\section{PEMBAHASAN}

Bakteri E. coli yang diduga penghasil ESBL ditunjukkan dengan adanya pertumbuhan pada MacConkay agar yang mengandung sefotaksim 1 $\mu \mathrm{g} / \mathrm{ml}$ dengan ciri koloni berbentuk bulat, halus, berwarna merah, dan dikelilingi zona keruh (Gambar 1a). MacConkey agar merupakan media selektif dan dapat membedakan antara bakteri enterik yang memfermentasi laktosa dan tidak memfermentasi laktosa. Sampel yang diduga E. coli penghasil ESBL juga ditumbuhkan pada media Levine eosin methylene blue agar (L-EMBA) dan Brilliance ${ }^{\mathrm{TM}}$ ESBL Agar dengan metode gores (Gambar 1b dan 1C). Ciri koloni yang diduga E. coli penghasil ESBL pada media
L-EMBA ditunjukkan dengan warna hijau metalik dengan titik hitam pada bagian tengah (Leininger et al., 2001). Warna hijau metalik dari L-EMBA mengindikasikan fermentasi laktosa yang sangat kuat. Koloni E. coli pada media Brilliance ${ }^{\mathrm{TM}}$ ESBL Agar berwarna biru karena bakteri memproduksi glukuronidase (Arul et al., 2008; Oxoid, 2010).

Uji konfirmasi ESBL pada penelitian ini menggunakan MASTDISCS ${ }^{\text {TM }}$ D68C yang pada prinsipnya sama dengan panduan dari Clinical and Laboratory Standar Institute (CLSI) (CLSI, 2014). E. coli penghasil ESBL paling banyak ditemukan pada sampel keranjang tempat kepala dan kaki $(n=4)$. Selanjutnya sepatu boot $(\mathrm{N}=2)$, kemudian besi penggantung karkas, truk, lantai pemotongan, dan sarung pisau $(n=1)$ (Tabel 1). Keranjang terkontaminasi feses maupun darah dari proses produksi sebelumnya. Mengingat bahwa mikrob yang berada di dalam feses atau kotoran sapi dapat bermigrasi ke lingkungan di sekitarnya (Ibrahim et al., 2016). Sumber kontaminasi di rumah potong hewan dapat berasal dari tanah sekitar, kulit, rambut, isi saluran pencernaan, darah, air, peralatan, dan fasilitas yang digunakan selama proses produksi (seperti pisau, katrol, pengait, dan peralatan di tempat jeroan), kotoran, udara, dan pekerja (Hansson, 2001; Sofos, 2008).

Hasil pengujian sensitivitas isolat $E$. coli penghasil ESBL terhadap antibiotik menunjukkan sifat resisten 
Tabel 2 Hasil pengujian sensitivitas isolat E. coli penghasil ESBL terhadap antibiotik

\begin{tabular}{lcccccccc}
\hline \multirow{2}{*}{ Kode sampel } & \multicolumn{3}{c}{ Antibiotik $^{\mathrm{a}}$} & & \multicolumn{3}{c}{ Total } \\
\cline { 2 - 8 } & $\mathrm{AMX}$ & $\mathrm{P}$ & $\mathrm{SXT}$ & $\mathrm{S}$ & $\mathrm{TE}$ & $\mathrm{R}$ & $\mathrm{I}$ & $\mathrm{S}$ \\
\hline 2/RKr1 & $\mathrm{R}$ & $\mathrm{R}$ & $\mathrm{S}$ & $\mathrm{I}$ & $\mathrm{S}$ & 2 & 1 & 2 \\
3/RKr1 & $\mathrm{R}$ & $\mathrm{R}$ & $\mathrm{R}$ & $\mathrm{R}$ & $\mathrm{S}$ & 4 & 0 & 1 \\
3/RSP & $\mathrm{R}$ & $\mathrm{R}$ & $\mathrm{S}$ & $\mathrm{I}$ & $\mathrm{S}$ & 2 & 1 & 2 \\
4/RKr1 & $\mathrm{R}$ & $\mathrm{R}$ & $\mathrm{R}$ & $\mathrm{R}$ & $\mathrm{R}$ & 5 & 0 & 0 \\
4/RSB & $\mathrm{R}$ & $\mathrm{R}$ & $\mathrm{R}$ & $\mathrm{I}$ & $\mathrm{S}$ & 3 & 1 & 1 \\
4/RKR2 & $\mathrm{R}$ & $\mathrm{R}$ & $\mathrm{R}$ & $\mathrm{R}$ & $\mathrm{S}$ & 4 & 0 & 1 \\
5/RSB & $\mathrm{R}$ & $\mathrm{R}$ & $\mathrm{R}$ & $\mathrm{R}$ & $\mathrm{S}$ & 4 & 0 & 1 \\
5/RBS & $\mathrm{R}$ & $\mathrm{R}$ & $\mathrm{S}$ & $\mathrm{R}$ & $\mathrm{S}$ & 3 & 0 & 2 \\
5/RTB & $\mathrm{R}$ & $\mathrm{R}$ & $\mathrm{I}$ & $\mathrm{R}$ & $\mathrm{R}$ & 4 & 1 & 0 \\
5/RLP & $\mathrm{R}$ & $\mathrm{R}$ & $\mathrm{R}$ & $\mathrm{R}$ & $\mathrm{R}$ & 5 & 0 & 0 \\
\hline AMX: & $\mathrm{R}$ & &
\end{tabular}

${ }^{a}$ AMX: amoksisilin; P: penisilin; SXT: trimethoprim sulfametoksasol; S: streptomisin; TE: tetrasiklin

S: Sensitif; I: Intermediet; R: Resisten

Tabel 3 Pola resistensi isolat E. coli penghasil ESBL terhadap antibiotik

\begin{tabular}{ccl}
\hline $\begin{array}{c}\text { Pola resistensi terhadap agen } \\
\text { antibiotik }\end{array}$ & Jumlah $(n)$ & \multicolumn{1}{c}{ Jenis $^{\text {a dan jumlah isolat }}$} \\
\hline 0 & 0 & 0 \\
1 & 0 & 0 \\
2 & 2 & $A M X+P(2)$ \\
3 & 2 & $A M X+P+S X T(1), A M X+P+S(1)$ \\
4 & 4 & $A M X+P+S X T+S(3), A M X+P+S+T E(1)$ \\
5 & 2 & $A M X+P+S X T+S+T E(2)$ \\
\hline
\end{tabular}

Keterangan: ${ }^{\mathrm{a} A M X}$ : amoksisilin; P: penisilin; SXT: trimethoprim sulfametoksasol; S: streptomisin; TE: tetrasiklin

minimal terhadap 2 jenis antibiotik, seperti pada Tabel 3. Antibiotik yang diujikan ialah penisilin, amoksisilin, streptomisin, trimetoprim-sulfametoksasol, dan tetrasiklin. Antibiotik tersebut termasuk ke dalam antibiotik yang biasa digunakan dalam pengobatan infeksi karena E. coli. Antibiotik yang biasa digunakan dalam pengobatan infeksi $E$. coli adalah ampisilin, karbenisilin, sefalotin, kloramfenikol, gentamisin, kanamisin, asam nalidiksid, norfloksasin, tetrasiklin, tikarsilin, tobramisin, trimetoprim-sulfametoksasol (McKee et al., 2003; Suwito dan Setyadji, 2011). Menurut Paterson (2000), ESBL menyebabkan resistensi terhadap antibiotik golongan penisilin, sefalosporin, dan aztreonam, selain itu juga terhadap kelas antibiotik lain, termasuk aminoglikosida, trimetoprim-sulfametoksasol, dan kuinolon.

Isolat E. coli menunjukkan resistensi yang cukup tinggi terhadap beberapa antibiotik. Tingkat resistensi paling tinggi adalah terhadap antibiotik penisilin (100\%), amoksisilin (100\%), streptomisin (70\%), trimetoprim sulfametoksasol (60\%), dan tetrasiklin (30\%) (Tabel 2). Resistensi yang muncul dipengaruhi oleh berbagai faktor risiko seperti penggunaan antibiotik yang tidak tepat pada hewan maupun manusia, baik untuk pencegahan maupun untuk pengobatan penyakit. Penggunaan antibiotik sebagai imbuhan pakan pada ternak (feed additive) yang digunakan terus menerus akan meningkatkan strain bakteri yang resisten terhadap antibiotik. Pemberian dalam dosis rendah secara rutin dalam pakan ternak dengan tujuan pencegahan penyakit dapat menyebabkan gangguan keseimbangan ekologi mikroflora normal dan berkurangnya kelompok bakteri sensitif, sementara kelompok bakteri yang resisten akan tumbuh subur. Dampak lain yang tidak diharapkan dari peningkatan strain bakteri yang resisten terhadap antibiotik pada ternak, dikhawatirkan dapat mengakibatkan kegagalan pengobatan dan perpanjangan pemakaian antibiotik pada manusia (Krisnaningsih, 2005; Kusumaningsih, 2012).

Sifat multi-drug resistance oleh bakteri terhadap antibiotik, termasuk golongan $\beta$-laktam, streptomisin, dan derivat tetrasiklin, sering dite-mukan dalam setiap kasus resistensi bakteri terhadap antibiotik, khususnya E. coli dan Salmonella sp. (Krisnaningsih, 2005). Kejadian resistensi pada E. coli penghasil ESBL terhadap beberapa jenis antibiotik dapat dikaitkan dengan penggunaan antibiotic yang 
dicampur pada pakan atau air minum. Konsentrasi antibiotik yang ditambahkan dalam pakan ternak merupakan dosis rendah, yaitu berkisar 2,5$12,5 \mathrm{mg} / \mathrm{kg}$ (ppm) terbukti dapat memacu terjadinya resistensi bakteri patogen dan bakteri komensal dalam saluran pencernaan (Noor dan Poeloengan, 2005).

Peningkatan biosekuritas rumah potong hewan untuk mencegah penyebaran E. coli penghasil ESBL di lingkungan harus dilakukan (Sudarwanto et al., 2016), mengingat bahwa rumah potong hewan sebagai reservoir terjadinya pencemaran bakteri yang resisten terhadap antibiotik, selain di lingkungan peternakan dan produk pangan asal hewan (Franklin et al., 2001; OIE, 2012).

Berdasarkan hasil penelitian disimpulkan bahwa isolat E. coli penghasil ESBL yang diisolasi dari sampel lingkungan di RPH-R Kota Bogor, memberikan gambaran adanya sensitivitas dan resistensi terhadap beberapa antibiotik. Pola resistensi, minimal terhadap dua jenis antibiotik. Isolat resisten terhadap penisilin sebesar $100 \%$, amoksisilin $100 \%$, streptomisin $70 \%$, trimetoprim-sulfametoksasol $60 \%$, dan tetrasiklin $30 \%$.

\section{UCAPAN TERIMA KASIH}

Ucapan terima kasih disampaikan kepada Penelitian Strategis Unggulan (PSU) Departemen IPHK FKH IPB, Laboratorium Divisi Kesehatan Masyarakat Veteriner, Departemen IPHK FKH IPB yang memberikan fasilitas sehingga penelitian ini dapat diselesaikan, BPPSDMP Kementerian Pertanian, dan BBKP Tanjung Priok.

"Penulis menyatakan tidak ada konflik kepentingan dengan pihak-pihak terkait dalam penelitian ini".

\section{DAFTAR PUSTAKA}

Aidara-Kane A, Andremont A, Collignon P. 2013. Antimicrobial resistance in the food chain and the AGISAR initiative. Journal of Infection and Public Health. 6:162-165.

Ariyanti T, Supar, Kusumaningsih A. 2007. Cemaran Escherichia coli pada bahan pangan asal ternak periode 2000-2004 dan resistensinya terhadap antibiotik. Prosiding seminar nasional hari pangan sedunia XXVII. Dukungan teknologi untuk meningkatkan produk pangan hewani dalam rangka pemenuhan gizi masyarakat. Bogor (ID): Badan Litbang Pertanian. 207-211.

Arul L, Benita G, Balasubramanian P. 2008. Bglucuronidase in Escherichia coli and Staphylococcus sp. RLH1. Bioinformation 2(8): 339-343.

Braun SD, Ahmed MFE, El-Adawy H, Hotzel H, Engelman I, Weib D, Moneckel S, Ehricht R. 2016. Surveillance of Extended Spectrum Beta lactamase producing Escherichia coli in dairy cattle farms in the Nile Delta, Egypt. Frontiers in Microbiology 7:1-14.

[BSN] Badan Standardisasi Nasional. 2008. SNI 2897: 2008 Tentang Metode Pengujian Cemaran Mikroba dalam Daging, Telur dan Susu Serta Hasil Olahannya. Jakarta (ID): Badan Standardisasi Nasional.

[CDC] Centers for Disease Control and Prevention. 2016. Escherichia coli. http://www.cdc.gov/ecoli. Download: April 10, 2016.

[CLSI] Clinical and Laboratory Standards Institute. 2014. Performance Standards for Antimicrobial Susceptibility Testing: Twenty-Second Informational Supplement. Wayne (US): Clinical and Laboratory Standards Institute.

Franklin A, Acar J, Anthony F, Gupta R, Nicholls T, Tamura $\mathrm{Y}$, Thompson S, Threlfall EJ, Vose D, Vuuren M, White DG, Wegener HC, Costarrica ML. 2001. Antimicrobial resistance: harmonisation of national antimicrobial resistance monitoring and surveillance programmes in animals and in animal-derived food. Scientific and Technical Review of the Office International des Epizooties 20(3):859-870.

Hansson IB. 2001. Microbiological meat quality in high and low capacity slaughterhouses in Sweden. Journal of Food Protection 64(6):820825.

Ibrahim DR, Dodd CER, Stekel DJ, Ramsden SJ, Hobman JL. 2016. Multidrug resistant, Extended Spectrum $\quad \beta$-Lactamase (ESBL)-producing Escherichia coli from a dairy farm. FEMS Microbiology Ecology 92(4):1-13.

Khanfar HS, Bindaynaz KM, Senok AC, Botta GA. 2009. Extended Spectrum Beta-Lactamases (ESBL) in Escherichia coli and Klebsiella pneumoniae: trends in the hospital and community settings. Journal of Infection in Developing Countries 3(4):295-299.

Krisnaningsih MMF, Asmara W, Wibowo MH. 2005. Uji sensitivitas isolat Eschericia coli patogen pada ayam terhadap beberapa jenis antibiotik. Jurnal Sain Veteriner 1:13-18. 
Kusumaningsih A. 2012. Faktor pemicu foodborne diseases asal ternak. Wartazoa 22(3): 107-112.

Leininger DJ, Roberson JR, Elvinger F. 2001. Use of eosin methylene blue agar to differentiate Escherichia coli from other gram-negative mastitis pathogens. Journal of Veterinary Diagnostic Investigation 13:273-275.

Loncaric I, Stalder GL, Mehinagic K, Rosengarten R, Hoelzi F, Knauer F, Walzer C. 2013. Comparison of ESBL-And AmpC producing Enterobacteriaceae and Methicillin-Resistant Staphylococcus aureus (MRSA) isolated from Migratory and Resident Population of Rooks (Corvus frugigelgus) in Austria. Plos One 8(12): 1-10.

Lukman DW, Sudarwanto M, Purnawarman T, Latif $H$, Pisestyani $H$, Sukmawinata $E$, Akineden $O$. 2016. CTX-M-1 dan CTX-M-55 producing Escherichia coli isolated from broiler feses in Poultry Slaughterhouse, Bogor, West Java Province. Global advanced research journal of medicine and medical science 5(12): 287-291.

McKee R, Maden RH, Gilmour A. 2003. Occurrence of verocytotoxin producing Escherichia coli in dairy and meat processing environment. Journal of Food Protection 66(9): 1576 -1580.

[Murdiati TB. 1997. Pemakaian antibiotik dalam usaha peternakan. Wartazoa 6(1): 18-22.

Noor SM, Poeloengan M. 2005. Pemakaian antibiotik pada ternak dan dampaknya pada kesehatan manusia. Prosiding lokakarya nasional keamanan pangan produk peternakan. Bogor (ID): Puslitbang Peternakan. 18-22.

[OIE] Office Internationale des Epizooties. 2012. Harmonisation of national antimicrobial resistance surveillance and monitoring programmes chapter 6.7. http://web.oie.int/eng/ normes/mcode/en_chapitre_1.6.7.pdf. Download : Februari 25, 2017.

Oxoid. 2010. Brilliance ${ }^{T M}$ ESBL. Oxoid. http://www. oxoid.com. Download: Februari 28, 2017.

Palaniappan RUM, Zhang Yu, Chiu D, Torres A, Debroy C, Whittam TS, Fu Chang Yung. 2006. Differentiation of Escherichia coli pathotypes by Oligonucleotide Spotted Array. Journal of Clinical Microbiology 44(4): 1495-1501.
Paterson DL. 2000. Recommendation for treatment of severe infections caused by Enterobacteriaceae producing Extended-Spectrum $\beta$ Lactamases (ESBLs). Clinical Microbiology and Infection Journal 6:460-463.

[PHAC] Public Health Agency of Canada. 2012. E. coli. http://www.phac-aspc.gc.ca/fs-sa/fs-fi/ecolieng.php. Download: April 10, 2016.

Pitout JDD, Laupland KB. 2008. Extended-Spectrum ß-Lactamase producing Enterobacteriaceae: An emerging public-health concern. The Lancet Infectious Diseases 8:159-66.

Sofos JN. 2008. Challenges to meat safety in the $21^{\text {st }}$ century. Meat Science 78: 3-13.doi:10.1016/ j.meatsci.2007.07.027.

Sousa CP. 2006. Escherichia coli as a specialized bacterial patogen. Revista De Biologia E Ciencias Da Terra. 6(2): 341-352.

Sudarwanto $M$, Akineden O, Odenthal S, Gross $M$, Usleber E. 2015. Extended Spectrum $\beta$-Lactamase $(\mathrm{ESBL})$ producing Klebsiella pneumoniae in bulk tank milk from dairy farms in Indonesia. Foodborne Pathogens and Disease 12(7):585-590.

Sudarwanto MB, Lukman DW, Latif $H$, Pisestyani $H$, Sukmawinata E, Akineden O, Usleber E. 2016. CTX$M$ producing Escherichia coli isolated from cattle feses in Bogor Slaughterhouse, Indonesia. Asian Pacific of Tropical Biomedicine 6(7): 605-608.

Sukmawinata E. 2015. Tingkat kejadian Escherichia coli penghasil Extended Spectrum B-Lactamase di feses sapi di rumah potong hewan ruminansia Kota Bogor. Tesis S2. Sekolah Pascasarjana, Institut Pertanian Bogor. Bogor.

Suwito W, Setyadji R. 2011. Uji kepekaan antibiotika Verotoksigenik E. coli (VTEC) yang diisolasi dari beberapa peternakan sapi perah di Jawa Barat. Seminar Nasional Teknologi Peternakan dan Veteriner. 376-383.

Van Elsas JD, Semenov AV, Costa R, Trevors JT. 2011. Survival of Escherichia coli in the environment: fundamental and public health aspects. The ISME Journal. 5:173-183.

Yuningsih. 2005. Keberadaan residu antibiotika dalam produk peternakan (susu dan daging). Lokakarya Nasional Keamanan Pangan Produk Peternakan. 48-55. 